\title{
PENGARUH PERSON ENVIROTMEN FIT DAN ORGANIZATION FIT TERHADAP KINERJA KARYAWAN PADA PT. BANK SULSELBAR CABANG PALOPO
}

\author{
Altri Wahida ${ }^{1}$ \\ Email : ${ }^{1}$ ) altri.wahida@yahoo.com
}

\author{
$\left.{ }^{1}\right)$ Program studi Manajemen, Sekolah Tinggi Ilmu Ekonomi Muhammadiyah Palopo
}

\begin{abstract}
Abstrak
Penelitian ini bertujuan untuk mengetahui apakah person environment fit dan organization fit berpengaruh signifikan terhadap kinerja karyawan pada PT. Bank Sulselbar cabang palopo. Adapun metode analisis yang digunakan dalam penelitian ini adalah metode deskriptif kualitatif, analisi regresi linear berganda, uji instrumen yaitu uji validasi dan uji reliabilitas, uji $\mathrm{T}$, dan uji $\mathrm{F}$ dengan bantuan program SPSS. Hasil analisis menunjukkan bahwa person environment fit dan organization fit berpengaruh signifikan terhadap kinerja karyawan pada PT. Bank Sulselbar cabang palopo. Hal ini ditunjukkan dengan nilai koefisien regresi 0,241 untuk variabel person environment fit dengan tingkat signifikan $0,047<0,05$ dan nilai koefisien regresi 0,643 untuk variabel organization fit dengan tingkat signifikan $0,001<0,05$.
\end{abstract}

Kata kunci : Person Environment Fit, Organization Fit, Dan Kinerja Karyawan

\section{PENDAHULUAN}

\section{Latar belakang}

Dalam dunia perbankan, keberhasilan usaha bank ditentukan oleh bagaimana manajemen melaksanakan aktivitas usahanya secara efektif untuk mencapai tujuan bank. Ada banyak cara yang dilakukan, seperti adanya pemisahan tugas, fungsi dan tanggung jawab yang jelas yang pada akhirnya akan mempengaruhi jalannya aktivitas bank.

Faktor yang mempengaruhi keberhasilan perbankan dalam melakukan aktivitas adalah kompetensi sumber daya manusia. Dimana menurut Wibowo (2008:86) bahwa kompetensi adalah suatu kemampuan untuk melakukan atau melaksanakan suatu pekerjaan atau tugas yang dilandasi atas keterampilan dan pengetahuan serta didukung oleh sikap kerja yang dituntut oleh pekerjaan tersebut.

Kinerja karyawan mengacu pada prestasi karyawan yang diukur berdasarkan standar atau kriteria yang telah ditetapkan oleh perusahaan.Upaya pengelolaan kinerja karyawan yang lebih tinggi ini terutama dimaksud untuk meningkatkan kinerja perusahaan secara keseluruhan. (Robbins, 2002:272) menjelaskan bahwa kriteria yang paling umum untuk menilai kinerja karyawan dapat dilihat dari tugas individu yang diberikan, perilakunya, dan ciri individunya.

Untuk melihat bagaimana motivasi dan kemampuan kerja dari masing-masing karyawan, maka pada PT. Bank Sulselbar cabang Palopo menerapkan sebuah sistem mengenai perpindahan tugas dari masing-masing karyawan (mutasi). Hal tersebut dilakukan untuk menilai bagaimana motivasi dan kemampuan kerja dari setiap individu setalah dilakukan perputaran (perpindahan) pekerjaan.

Dalam menghadapi persaingan yang cukup kompetitif dilingkungan perbankan saat ini, mengharuskan pihak bank untuk dapat lebih cermat mengambil strategi guna mempertahankan bahkan diharapkan dapat meningkatkan kompetensi kinerja karyawan karena dari tahun ke tahun persaingan dalam dunia kerja semakin ketat. Oleh karena itu, PT. Bank Sulselbar cabang Palopo melakukan perpindahan tugas dari masing-masing karyawan agar supaya kemampuan setiap karyawan dapat diukur. Hal ini bertujuan untuk mengurangi risiko yang tidak diinginkan didalam kinerja karyawan karena dapat menghambat jalannya pekerjaan yang telah dibebankan kepadanya.

Faktorpenyebab terjadinya permasalahan akhir-akhir ini yang dihadapi oleh PT. Bank Sulselbar Cabang Palopo yaitu perpindahan tugas dari masing-masing karyawan (mutasi) yang tidak sesuai dengan skill yang dimilikinya sehingga terjadi kesalahan-kesalahan pencetakan. Untuk itu, kemampuan dan motivasi harus di utamakan dalam bekerja agar supaya pekerjaan dapat berjalan sesuai apa yang di ingin tercapai.

Selain dari bekerja secara individual, maka bekerja secara organisasi atau kelompok turut berpengaruh terhadap kinerja karyawan, bekerja secara organisasi atau kelompok semua pekerjaan terasa ringan dikerjakan, hal itu dapat memberikan energi positif bagi karyawan dan keuntungan bagi pihak bank sendiri. Bekerja secara organisasi harus saling berinteraksi terutama untuk berbagi informasi dan membuat berbagai keputusan dalam membantu setiap anggota bekerja didalam area tanggung jawabnya masing-masing. Agar apa yang telah ditargetkan sebelumnya dapat tercapai dengan baik. 
Menurut Herzberg memandang bahwa person environment fit dan organization fit mempengaruhi kinerja karyawan dapat menunjukkan bahwa seseorang cenderung akan termotivasi dalam bekerja apabila saling bekerja sama dilingkungan organisasi dan saling berinterkasi satu sama lain.

Berdasarkan uraian di atas, maka penulis tertarik untuk melakukan penelitian dengan judul " Pengaruh Person Environment Fit dan Organization Fit Terhadap Kinerja Karyawan pada PT. Bank Sulselbar Cabang Palopo"

\section{Rumusan Masalah}

Berdasarkan latar belakang sebelumnya, maka masalah pokok yaitu ,

1. Apakah Person Environment Fit berpengaruh signifikan terhadap kinerja karyawan ?

2. Apakah Organization Fit berpengaruh signifikan terhadap kinerja karyawan ?

\section{Tujuan Penelitian}

Berdasarkan rumusan masalah yang telah dikemukakan sebelumnya, maka tujuan dalam penelitian ini adalah sebagai berikut :

1. Untuk mengetahui apakahperson environment fit berpengaruh signifikan terhadap kinerja karyawan pada PT. Bank Sulselbar Cabang Palopo.

2. Untuk mengetahui apakah organization fit berpengaruh signifikan terhadap kinerja karyawan pada PT. Bank Sulselbar Cabang Palopo.

\section{TINJAUAN PUSTAKA}

\section{Manajemen Sumber Daya Manusia}

Manajemen sumber daya manusia adalah pendekatan terhadap manajemen terhadap manajemen manusia.Pendekatan terhadap manajemen manusia tersebut didasarkan pada nilai manusia dalam hubungannya dengan organisasi. Disamping itu efektifitas organisasi ditentukan oleh manajemen sumber daya manusia.

Rachmawati (2008 : 3) mengemukakan bahwa manajemen sumber daya manusia merupakan suatu proses perencanaan, pengorganisasian, pengarahan dan pengawasan kegiatan-kegiatan pengadaan, pengembangan, pemberian kompensasi, pengintegrasian, pemeliharaan dan pelepasan sumber daya manusia agar tercapai berbagai tujuan individu, organisasi dan masyarakat.

Dessler (2000 : 2) mengemukakan bahwa manajemen sumber daya manusia adalah proses memperoleh, melatih, menilai dan memberikan konpensasi kepada karyawan, memperhatikan hubungan kerja mereka, kesehatan, keamanan serta masalah keadilan.

Fathoni (2006 :9) mengemukakan bahwa manajemen sumber daya manusia adalah proses pengendalian berdasarkan fungsi manajemen tehadap daya yang bersumber dari manusia.
Manajemen sumber daya manusia dapat diartikan sebagai proses serta upaya untuk merekrut, mengembangkan, memotivasi, serta mengevaluasi keseluruhan sumber daya manusia yang diperlukan perusahaan dalam pencapaian tujuannya. Hal ini mencakup dari mulai siapa saja yang memiliki kualifikasi dan pantas untuk menempati posisi dalam perusahaan (the man on the right place) seperti disyaratkan perusahaan sebagaimana agar kualifikasi ini dapat dipertahankan bahkan ditingkatkan serta dikembangkan dari waktu ke waktu. Oleh karena manajemen sumber daya manusia ini merupakan proses yang berkelanjutan sejalan dengan proses operasionalisasi perusahaan, maka perhatian terhadap sumber daya manusia ini memiliki tempat yang khusus dalam organisasi perusahaan.

Manajemen sumber daya manusia diperlukan untukmeningkatkan kemampuan dan memberikan motivasi kepada pemimpin dan karyawan dalam berorganisasi. Tujuannya adalah untuk menangani berbagai masalah pada ruang lingkung pemimpin dan karyawan untuk dapat menunjang aktvitas organisasi atau perusahaan demi mencapai tujuan tertentu.

Perusahaan yang ingin memperoleh karyawan yang memiliki kemampuan dan motivasi semangat kerja yang tinggi, sehingga kualitas dan kedisiplinan kerja meningkat, perlu adanya suatu upaya seorang pimpinan. Disinilah sangat penting untuk disadari oleh pimpinan perusahaan mengenai teknik-teknik apa saja yang dapat mendongkrak dan memelihara prestasi dan disiplin kerja karyawan. Salah satu usaha untuk meningkatkan kualitas dan kedisiplinan kerja tersebut adalah melalui pemberian motivasi terhadap karyawan agar dapat memberikan kemampuan terbaiknya dalam rangka pencapaian tujuan perusahaan.

\section{Pengertian Person Environment Fit}

Menurut Brown dalam ballout memaparkan bahwa person environment fit dapat didefenisikan sebagai kesesuaian yang terjadi ketika karakteristik individual dan lingkungan kerja sangat cocok satu sama lain. Enfironment fit para peneliti (ostroff et al, kristof brown et al, cable dan derue, bretz dan judge), dalam ballout menyarankan bahwa jenis fit yang berbeda dan gagal memainkan peranan penting dalam keputusan pilihan pekerjaan atau karir, dan bahwa setiap bentuk dari fit berpengaruh besar dalam bidang seperti kepuasan kerja, kinerja, komitmen, dan career-related outcomes dalam ballout. Sebagaimana harapan individu untuk bekerja lebih banyak dan dalam batasan-batasan proyek, jalur karir dan kebijakan yang mendukung kinerja karir serta perilaku dalam memilih pekerjaan, diharapkan menjadi lebih penting bagi kemajuan tertentu.

Person environment membantu menentukan seberapa baik karir fit dan dalam kelompok kerja tertentu atau subkultur karena fit termasuk di dalamnnya perasaan nyaman dengan organisasi. Person Environment Fit memberikan kerangka pemahaman karir yang bermanfaat untuk menyelidiki dimana praktek dari kemajuan karir dapat dibetuk oleh nilai karir dan individu yang menghargai 
dan berbagi untuk mengembangkan karirnya. Personenvironment fit memberikan interaksi dari individu dan variabel situasional untuk menjelaskan employability dan pengembangan karir dari individu secara signifikan. Person environment memberikan banyak arah termasuk meningkatkan kepuasaan individu dan komitmen.Person environment memberikan dampak langsung atas kepuasaan karir individu dan kemajuannya melalui partisipasi aktif dalam perusahaan berbasis knowledgeintensive, dimana identitas karir direkontruksi dan loyalitasnya diperkuat oleh manajemen puncak untuk menyelaraskan norma dan nilai yang diberikan oleh budaya korporasi organisasi dari (person-environment fit). Rekontruksi identitas korporasi yang terdiri atas individu sebagai produk sosial dari power relations. Prospek pengembangan karir melibatkan komitmen individu untuk bekerja keras dan menjadi profesional menurut standar lokal.Individu semakin giat untuk mendefinisikan dirinya sebagai individu yang terbenam dalam penciptaan dan pemeliharaan.

Konsep person environment fit telah diuraikan sebagai dugaan menyeluruh yang meliputi satu kecocokan dengan berbagai sistem di dalam lingkungan kerja. Asumsi yang mendasari perspektif person enfironment fit adalah bahwa besarnya tingkat dari fit antar individu dan lingkungan menghasilkan manfaatmanfaat atau hasil-hasil untuk individu. Teori dari person-environment fit membantu psikologi organisatoris dalam mempertimbangkan bagaimana karakteristik individu dan situasional dikombinasikan untuk mempengaruhi hasil yang dicapai oleh individu dan perilaku-perilaku lain dalam suatu lingkungan. Teori environment fit telah digunakan secara ektensif untuk menjelaskan perbedaan-perbedaan individu dan tradisitradisi psikologi organisatoris. Sebagai contoh teori yang sudah mendukung perspektif person environment fit meliputi kepribadian, budaya organisasi dan iklim organisasi. Sebagian besar studi pada person environment fit membandingkan atribut-atribut individu (seperti nilainilai dan kebutuhan-kebutuhan) dan karakteristikkarakteristik situasional atau organisasional (seperti lapangan pekerjaan dan jenis jabatan) untuk memprediksi dan menjelaskan hasil-hasil yang menguntungkan berhubungan dengan peningkatan fit dengan perspektif yang berbeda pada fit dan hubungan person enfironment fit membangun perilaku-perilaku yang terkait dengan karir individual (seperti keterlibatan karir dan kesuksesan karir) hingga proses-proses organisatoris (seperti atraksi organisatoris dan pemilihan).

Harrison dalam Furnham dan Schaeffrer menyarankan dua macam dari person environment fit. Pertama, persyaratan pekerjaan.Kedua, sejauh mana lingkungan pekerjaan menyediakan sumber daya untuk memenuhi kebutuhan individu.Ketidakcocokan dari salah satu dari dua hal tersebut dapat mengancam kesejahteraan individu dan mengakibatkan berbagai efek yang tidak diinginkan atas kepuasan kerja dan kesehatan.

Faktor-faktor yang mempengaruhi person environment fit menurut Mangkuprawira (2007:113) yaitu:
1. Kemampuan

Kemampuan sesungguhnya merupakan suatu unsur pelaksanaan kerja yang diperlukan untuk memungkinkan para karyawan bekerja dengan cara tertentu. Sejauh mana kemampuan seorang pegawai menyelesaikan suatu kegiatan seringkali bergantung pada tingkat pengetahuan, keterampilan dan keahlian yang dimilikiyang sesuai dengan tugas yang di berikan kepadanya.

2. Motivasi

Motivasi merupakan pemberian suatu dorongan kebutuhan dari karyawan yang perlu dipenuhi agar karyawan tersebut dapat menyeimbangkan dan mengarahkan diri terhadap pencapaian tujuan yang ditetapkan.

\section{Pengertian Organization Fit}

Menurut para ahli terdapat beberapa pengertian organisasi sebagai berikut :

1. Organisasi Menurut Stoner adalah suatu pola hubungan-hubungan yang melalui mana orangorang di bawah pengarahan manajer mengejar tujuan bersama.

2. Organisasi Menurut Mooney adalah bentuk setiap perserikatan manusia untuk mencapai tujuan bersama.

Jadi organisasi adalah sekelompok orang yang bekerjasama, struktur dan koordinasi tertentu dalam tujuan. Timpe (1999:6) mengemukakan bahwa organization fit adalah serangkaian sifat yang dapat diukur berdasarkan persepsi kolektif dari orang-orang yang hidup dan bekerja dalam lingkungan tersebut dan biasanya mempengaruhi motivasi dan perilaku mereka.

Lussier (2005:486) mengemukakan bahwa organization fit adalah persepsi karyawan mengenai kualitas lingkungan organisasi yang secara relatif dirasakan oleh anggota organisasi yang kemudian akan mempengaruhi perilaku mereka berikutnya.

Berdasarkan definisi di atas, maka organization fit merupakan suatu konsep yang menggambarkan tentang kualitas lingkungan organisasi yang mempengaruhi perilaku anggota organisasi dalam melaksanakan pekerjaannya.

Faktor-faktor yang mempengaruhi berorganisasi yaitu

\section{Leadership}

Kepemimpinan meliputi proses dalam menentukan tujuan organisasi, memotivasi perilaku pengikut untuk mencapai tujuan. Hal ini dapat dilihat dari keberhasilan seorang pemimpin dalam menggerakkan orang lain dalam mencapaitujuan yang telah ditetapkan sangat tergantung kepada kewibawaan, dan juga pemimpin itu dalam menciptakanmotivasi dalam diri setiap bawahannya maupun atasan pemimpin itu sendiri.

2. Budaya

Budaya organisasi didefenisikan sebagai nilai-nilai dan cara bertindak yang dianut organisasi dalam hubungannya dengan pihak luar. 


\section{Iklim organisasi}

Iklim organisasi merupakan suatu konsep yang menggambarkan tentang kualitas linkungan organisasi yang mempengaruhi perilaku anggota oganisasi dalam melaksanakan pekerjaan.

Stephen (2002 : 294) budaya melakukan sejumlah fungsi didalam sebuah organisasi. Fungsi-fungsi budaya organisasi yakni :

1. Budaya mempunyai suatu peran menetapkan batas artinya budaya menciptakan perbedaan yang jelas antara organisasi yang lain.

2. Budaya membawa suatu rasa identitas bagi anggotaanggota organisasi.

3. Budaya mempermudah timbulnya komitmen pada sesuatu yang lebih luas dari pada kepentingan diri individual seseorang.

4. Budaya berfungsi sebagai mekanisme pembuat makna dan kendali yang memandu dan membentuk sikap serta perilaku para karyawan.

Adapun tujuan seseorang bergabung ke dalam suatu kelompok organisasi adalah:

1. Kelompok atau organisasi sering dipakai untuk memecahkan masalah-masalah.

2. Mencegah kesepian dan kerenggangan

3. Kelompok dapat memberikan bantuan pada saat kesusahan / menjumpai masalah.

4. Kelompok dapat memberikan tujuan dan nilai hidup yang lebih baik, perilaku, dan kesetaraan kelompok.

5. Kelompok social, kerja dan bermacam-macam kelompok lainnya memberikan status dan pengakuan.

\section{Kinerja karyawan}

Kinerja karyawan menurut As'ad (2001:48) keberhasilan seseorang pekerja terkait dengan keberhasilan dalam menyelesaikan tugasnya. Hal tersebut dapat dilihat dari sisi kualitas, ketepatan waktu dalam menyelesaikan pekerjaan tersebut.

Kinerja karyawan menurut Sulistiyani dan Rosidah (2003:223) merupakan kombinasi dari kemampuan, usaha dan kesempatan yang dapat dinilai dari hasil kerjanya.

Menurut Sentono (1999:2) kinerja karyawan merupakan hasil kerja yang dapat dicapai oleh seorang atau sekelompok orang dalam suatu organisasi sesuai dengan wewenang dan tanggung jawab masing-masing dalam rangka mencapai tujuan organisasi bersangkutan secara legal, tidak melanggar hukum dan sesuai dengan moral maupun etika.

Sedangkan menurut Davis (2004:67) menyatakan kinerja merupakan kemampuan dan motivasi.

Dapat disimpulkan bahwa kinerja karyawan adalah suatu hasil kerja yang dicapai seseorang dalam melaksanakan tugas-tugas yang dibebankan kepadanya yang didasarkan atas kecakapan, pengalaman dan kesungguhan serta waktu.

Kinerja merupakan suatu fungsi dari motivasi dan kemampuan menyelesaikan tugas atau pekerjaan seseorang sepatutnya memiliki derajat kesediaan dan tingkat kemampuan tertentu. Kesediaan dan keterampilan seseorang tidaklah cukup efektif untuk mengerjakan sesuatu tanpa pemahaman yang jelas tentang apa yang akan dikerjakan dan bagaimana mengerjakannya. Kinerja merupakan perilaku nyata yang ditampilkan setiap orang sebagai prestasi kerja yang dihasilkanoleh pegawai sesuai dengan perannya dalam perusahaan.Kinerja pegawai merupakan suatu hal yang sangat penting dalam upaya perusahaan untuk mencapai tujuannya.

Gie (1999:17) menyatakan bahwa kinerja sangat ditentukan oleh beberapa faktor yaitu :

1. Motivasi kerja

Motivasi kerja merupakan pemberian pengarahan, dorongan atau semangat kepada para karyawan agar mampu bekerja sesuai dengan tujuan yang diharapkan, demi tercapainya tujuan organisasi dalam suatu perusahaan dengan efektif dan efisien.

2. Kemampuan kerja

Kemampuan kerja merupakan suatu kapasitas individu untuk mengerjakan berbagi tugas dalam suatu pekerjaan.

3. Perlengkapan atau fasilitas

Perlengkapan atau fasilitas merupakan barangbarang yang digunakan untuk menghasilkan suatu pekerjaan yang diharapkan di kantor.

4. Leadership

Perilaku pemimpin mempengaruhi iklim organisasi yang kemudian mendorong motivasi karyawan merupakan pendorong utama terjadinya kinerja.

5. Budaya perusahaan

Budaya perusahaan adalah suatu pola asumsi dasar yang dimiliki oleh anggota perusahaan yang berisi nilai-nilai, norma-norma, dan kebiasaan yang mempengaruhi pemikiran, pembicaraan, tingkah laku dan cara kerja karyawan sehari-hari, sehingga akan menciptakan kualitas kerja perusahaan yang baik.

6. Kinerja individu dan organisasi

Kinerja individu dan organisasi didefenisikan sebagai kuantitas dan kualitas pencapaian tugastugas, baik yang dilakukan oleh individu maupun organisasi.

7. Struktur

Pola hubungan antar bagian dalam rangka pelaksanaan tugas-tugas berlangsung dengan baik dan lancar tanpa hambatan dan juga dimana hubungan atasan dengan bawahan berlangsung harmonis dan saling berkoordinasi sesuai jalur struktur yang ditetapkan oleh perusahaan.

8. Iklim kerja

Iklim kerja merupakan suatu konsep yang menggambarkan tentang kualitas lingkungan organisasi yang mempengaruhi kinerja karyawan dan organisasi dalam melaksanakan pekerjaan.

Menurut Newstom (1985) ada dua faktor utama yang mempengaruhi kinerja karyawan yaitu :

1. Kemampuan

Kemampuan seseorang pegawai sangat di tentukan oleh pengetahuan dan keterampilan yang dimilikinya serta latar belakang pendidikan yang sesuai dengan jabatan dan IQ serta terampil dalam 
mengerjakan pekerjaan sehari-hari dengan mudah akan mampu mencapai kinerja yang diharapkan.

2. Motivasi

Motivasi terbentuk dari sikap seseorang pegawai dalam menghadapi situasi kerja. Sikap yang diharapkan dari seorang karyawan adalah sikap mental, fisik, dan situasi agar dapat mencapai target yang diinginkan serta mampu memanfaatkan dan menciptakan situasi kerja yang kondusif selanjutnya akan mencapai tujuan organisasi.

Menurut Jakson (2001:308) faktor-faktor yang mempengaruhi kinerja karyawan organisasi :

1. Jumlah kerja

Merupakan hasil jumlah keseluruhan karyawan yang bekerja dengan masing-masing tanggungjawab yang dibebankan kepada setiap karyawan.

2. Kualitas kerja

Kualitas kerja menunjukkan sejauh mana mutu seorang pegawai dalam melaksanakan tugastugasnya meliputi ketepatan, kelengkapan, dan kerapian setiap pekerjaan.

3. Kecocokan dengan rekan kerja

Merupakan semangat rekan kerja dalam melakukan pekerjaan dan saling membantu dalam mengatasi kesulitan rekan kerja lainnya dalam meraih prestasi kerja.

4. Kehadiran

Kehadiran atau partisipasi karyawan dalam aktivitas-aktivitas kerja penting untuk diperhatikan karena adanya keterlibatan karyawan menyebabkan mereka akan mau dan senang bekerja sama baik dengan pemimpin ataupun dengan sesama teman kerja.

5. Masa bakti

Merupakan jangka waktu kerja yang telah disepakati bersama pada saat memulai bergabung bekerja pada perusahaan.Penilaian kinerja karyawan merupakan suatu metode.untuk melakukan evaluasi terhadap kinerja karyawan disebuah perusahaan.

Ada beberapa cara penilaian kinerja karyawan :

1. Evaluasi yang dilakukan dengan melakukan perbandingan antar orang

2. Pengembangan sumber daya karyawan

3. Pemeliharaan sistem kerja perusahaan

4. Dokumentasi terhadap keputusan-keputusan terkait sumber daya manusia.

\section{METODE PENELITIAN}

\section{Lokasi Dan Waktu Penelitian}

Penulis akan melakukan penelitian pada PT. Bank Sulselbar Cabang Palopo yang berlokasi di Jl. Andi Baso Rahim No. 01 Palopo. Adapun waktu penelitian dilakukan \pm 1 bulan.

\section{Jenis Dan Sumber Data}

Adapun jenis dan sumber data yang digunakan yaitu :

\section{Jenis data}

a. Data kualitatif, yaitu data yang diperoleh melalui catatan atau tulisan berbagai sumber seperti studi pustaka, dan jurnal yang berkaitan dengan penelitian.

b. Data kuantitatif, yaitu data dalam bentuk angka berupa data jumlah karyawan pada PT. Bank Sulselbar Cabang Palopo.

\section{Sumber data}

a. Data primer yaitu data yang diperoleh secara langsung melalui kuesioner yang disebar dan wawancara pada responden, serta data lainnya yang menunjang pokok pembahasan ini.

b. Data sekunder yaitu data yang diperoleh dengan cara mengumpulkan informasi dan dokumendokumen, serta literatur yang berkaitan dengan masalah yang diteliti.

\section{Populasi Dan Sampel}

Menurut Sugiyono (2011:126) dalam hal ini sampel adalah bagian dari jumlah dan karakteristik yang dimiliki oleh populasi. Untuk menentukan sampel menggunakan Probbability Sampling yaitu teknik pengambilan sampel yang memberikan peluang yang sama bagi setiap unsur (anggota) populasi untuk dipilih menjadi anggota sampel. Salah satu teknik Probbability Sampling yang digunakan metode Sampling Jenuh. Sampling jenuh adalah metode penentuan sampel bila semua anggota populasi dijadikan sampel. Hal ini sering dilakukan bila jumlah populasi relatif kecil. Berdasarkan data dari PT. Bank Sulselbar cabang Palopo dimana jumlah karyawan sebanyak 30 orang maka jumlah sampel sebanyak 30 orang.

\section{ANALISIS DATA}

Untuk menjawab masalah pokok yang dikemukakan maka metode analisis yang digunakan adalah:

1. Analisis Deskriptif

Analisis yang menguraikan tanggapan responden mengenai person environment fit dan organization fit terhadap kinerja karyawan melalui kuesioner yang dibagikan dengan menggunakan indikator Skala Likert, yang pengukurannya adalah : (1) Sangat Tidak setuju (STS), (2) Tidak Setuju (TS),

(3) Netral (N), (4) Setuju (S), (5) Sangat Setuju (SS).

2. Analisis Regresi Linear Berganda

Analisis regresi linear berganda dalam penelitian ini digunakan untuk mengetahui besarnya pengaruh variabel independen (person environment fit dan organization fit) terhadap variabel dependen (kinerja karyawan). Analisis data akan menggunakan software SPSS 16.0 For Windows. Sebagaimana dikutip dari buku Riduwan (2003:252253).

$$
\mathbf{Y}=\mathbf{a}+\mathbf{b}_{1} \mathbf{X}_{1}+\mathbf{b}_{2} \mathbf{X}_{2}+\mathbf{e}
$$

Keterangan :

$\mathrm{Y}=$ Kinerja Karyawan

$$
\mathrm{a}=\text { Konstanta }
$$




$$
\begin{aligned}
& \mathrm{b}_{1} \mathrm{~b}_{2}=\text { Paremeter regresi } \\
& \mathrm{X}_{1}=\text { person environment fit } \\
& \mathrm{X}_{2}=\text { organization fit } \\
& \mathrm{e} \quad=\text { Standar error }
\end{aligned}
$$

3. Uji Validasi

Uji validasi dilakukan untuk mengetahui tingkat keandalan alat ukur yang digunakan. Instrumen dikatakan valid berarti menunjukkan alat ukur yang digunakan untuk mengukur apa yang seharusnya diukur. Pengujian dilakukan dengan menggunakan software SPSS 16.0 For Windows dilakukan dengan melihat output Corrected Item - Total Correlation dimana jika $r_{\text {hitung }}>r_{\text {tabel }}$ berarti butir pertanyaan telah valid.

4. Uji Reliabilitas

Uji reliabilitas merupakan kemampuan suatu instrumen untuk diuji kembali dengan memberikan hasil yang relatif konstan. Suatu instrumen dikatakan reliable jika memberikan hasil yang relatifsama jika diuji secara berulang-ulang. Pada analisis ini digunakan Chronbach Alpha.

5. Uji T / Parsial

Pengujian ini dilakukan untuk mengetahui apakah pengaruh masing-masing variabel bebas terhadap variabel terikat apakah bermakna atau tidak. Pengujian dilakukan sebagai berikut :

a. Bila $t_{\text {hitung }}>t_{\text {tabel }}$ maka $\mathrm{H}_{0}$ ditolak dan $\mathrm{H}_{\mathrm{a}}$ diterima, artinya ada pengaruh variabel bebas terhadap variabel terikat.

b. Bila $t_{\text {hitung }}>t_{\text {tabel }}$ maka $\mathrm{H}_{0}$ diterima dan $\mathrm{H}_{\mathrm{a}}$ ditolak, artinya tidak ada pengaruh variabel bebas terhadap variabel terikat.

6. Uji F / Simultan

Uji ini digunakan untuk mengetahui apakah seluruh variabel bebasnya secara bersama-sama mempunyai pengaruh yang bermakna terhadap variabel terikat. Pengujian dilakukan sebagai berikut :

a. Bila $f_{\text {hitung }}>f_{\text {tabel.ditolak dan }} \mathrm{H}_{\mathrm{a}}$ diterima, artinya semua variabel bebas secara bersamasama berpengaruh terhadap variabel terikat.

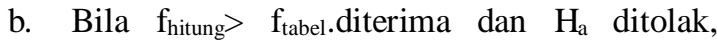
artinya semua variabel bebas secara bersamasama tidak berpengaruh terhadap variabel terikat.

\section{HASIL PENELITIAN DAN PEMBAHASAN}

\section{Gambaran Umum Penelitian}

PT. Bank Sulselbar Cabang Palopo adalah perusahaan yang bergerak dibidang jasa perbankan, yang dimana harus dapat memberikan pelayanan yang terbaik untuk dapat memenangkan persaingan yang semakin hari semakin kompetitif. Untuk menghadapi persaingan antar lembaga perbankan yang semakin ketat, sekarang ini telah dikembangkan dalam berbagai konsep pelayanan nasabah dengan tujuan untuk mempertahankan nasabah dan menjangkau nasabah potensial.
Tugas pokok suatu Bank adalah menghimpun dana dari masyarakat dan menyalurkan kembali dana tersebut kepada masyarakat yang memerlukannya. Untuk melaksanakan kegiatan operasional perusahaan khusus PT. Bank Sulselbar cabang Palopo, tugas dan tanggung jawab dipercayakan kepada masing-masing divisi yang terdiri dari divisi Akuntansi dan informasi, divisi Sekretariat dan Umum dan divisi Pemasaran. Untuk itu diperlukan kerjasama yang baik antar karyawan dan harus berusaha untuk menghasilkan kinerja sebaik mungkin sehingga dapat memberikan prestasi kepada perusahaan.

\section{HASIL PENELITIAN}

\section{Analisis Deskriptif Karakteristik Responden}

Analisis deskriptif karakteristik responden dilakukan dengan tujuan untuk mengidentifikasi responden, dimana dalam melakukan penelitian ini ditetapkan sebanyak 30 sampel sebagai responden dengan menggunakan metode Sampling Jenuh.

Karyawan PT. Bank Sulselbar Cabang Palopo memiliki karakteristik yang beragam yang merupakan gambaran objek penelitian yang memberikan interprestasi identitas responden atau karakteristik dari karyawan. Perbedaan yang diperlihatkan oleh hasil penelitian tidak dibedakan dengan sengaja, tetapi diambil berdasarkan tehnik pengambilan sampel dengan penjelasan sebagai berikut yaitu berdasarkan :

a. Deskriptif responden berdasarkan jenis kelamin

Tabel 4.1

Data responden berdasarkan jenis kelamin

\begin{tabular}{|c|c|c|}
\hline Jenis kelamin & $\begin{array}{c}\text { Jumlah ( orang } \\
\text { ) }\end{array}$ & \% \\
\hline Laki-laki & 12 & $\mathbf{4 0}$ \\
\hline Perempuan & 18 & $\mathbf{6 0}$ \\
\hline Total & 30 & $\mathbf{1 0 0}$ \\
\hline
\end{tabular}

Sumber : data diolah, 2018

Data tabel 4.1 menggambarkan sebagian besar responden dalam penelitian ini adalah perempuan yaitu sebanayk 18 orang, sedangkan laki-laki sebanyak 12 orang.

b. Deskriptif responden berdasarkan usia

Tabel 4.2

Data responden berdasarkan jenis kelamin

\begin{tabular}{|c|c|c|}
\hline Usia & $\begin{array}{c}\text { Jumah } \\
\text { (orang) }\end{array}$ & $\%$ \\
\hline$<25$ tahun & 2 & 6,67 \\
\hline $26-35$ tahun & 18 & 60 \\
\hline $36-45$ tahun & 7 & 23,3 \\
\hline$>45$ tahun & 3 & 10 \\
\hline Total & 30 & 100 \\
\hline
\end{tabular}

Sumber: data diolah, 2018 
Data tabel 4.2 menggambarkan data responden berdasarkan usia bahwa kebanyakan umur responden antara 26-35 tahun yaitu 18 orang, sedangkan yang terkecil umur responden $<25$ tahun sebanyak 2 orang.

c. Deskriptif responden berdasarkan jenis pendidikan.

Tabel 4.3

Data responden berdasarkan jenis pendidikan

\begin{tabular}{|c|c|c|}
\hline Jenis pendidikan & $\begin{array}{c}\text { Jumlah } \\
\text { (orang) }\end{array}$ & $\boldsymbol{\%}$ \\
\hline SMA/SEDERAJAT & 4 & $\mathbf{1 3 . 3}$ \\
\hline Diploma & 2 & $\mathbf{6 . 6 7}$ \\
\hline Sarjana (S1) & 24 & $\mathbf{8 0}$ \\
\hline Pasca sarjana (S2) & - & - \\
\hline Total & 30 & $\mathbf{1 0 0}$ \\
\hline
\end{tabular}

Sumber: data diolah, 2018

Tabel 4.3 menggambarkan data responden berdasarkan pendidikan, dimana pendidikan responden yang dominan adalah sarjana (S1) yaitu 22 orang, sedangkan yang terkecil adalah berpendidikan Diploma yaitu 2 orang.

\section{Pengujian Validitas dan Reliabilitas}

a. Uji Validitas. Pengukuran pada penelitian ini yang digunakan yaitu metode one shot, dimana pengukuran keandalan butir pertanyaan dilakukan dengan sekali menyebarkan kuesioner pada responden, kemudian hasil skornya diukur korelasinya antar skor jawaban pada butir pernyataan yang sama dengan bahan SPSS. Untuk hasil lengkap dari uji validitas dapat dilihat pada tabel 4.4

Tabel 4.4

Hasil Uji Validitas Instrumen

\begin{tabular}{|c|c|c|}
\hline Instrumen & $\begin{array}{c}\text { Corrected } \\
\text { Item-total } \\
\text { Correlation }\end{array}$ & \\
\hline Person Environment Fit & & \\
Ev1 & & \\
Ev2 & 0,799 & Valid \\
Ev3 & $\mathbf{0 , 3 6 3}$ & Valid \\
Ev4 & $\mathbf{0 , 7 2 1}$ & Valid \\
Ev5 & $\mathbf{0 , 5 6 0}$ & Valid \\
Ev6 & $\mathbf{0 , 7 9 4}$ & Valid \\
Ev7 & $\mathbf{0 , 7 9 4}$ & Valid \\
& $\mathbf{0 , 3 5 2}$ & Valid \\
Organization Fit & & \\
Or1 & & \\
Or2 & & \\
Or3 & $\mathbf{0 , 4 4 0}$ & Valid \\
Or4 & $\mathbf{0 , 5 4 5}$ & Valid \\
Or5 & $\mathbf{0 , 3 1 5}$ & Valid \\
Or6 & $\mathbf{0 , 4 1 1}$ & Valid \\
Or7 & $\mathbf{0 , 4 8 4}$ & Valid \\
& $\mathbf{0 , 6 5 4}$ & Valid \\
Kinerja Karyawan & $\mathbf{0 , 5 4 5}$ & Valid \\
KK1 & &
\end{tabular}

\begin{tabular}{|l|l|l|}
\hline $\mathbf{K K}_{2}$ & $\mathbf{0 , 4 9 0}$ & Valid \\
$\mathbf{K K}_{3}$ & $\mathbf{0 , 3 3 8}$ & Valid \\
$\mathbf{K K}_{4}$ & $\mathbf{0 , 7 6 1}$ & Valid \\
$\mathbf{K K}_{\mathbf{5}}$ & $\mathbf{0 , 5 6 1}$ & Valid \\
KK $_{6}$ & $\mathbf{0 , 5 8 6}$ & Valid \\
$\mathrm{KK}_{7}$ & $\mathbf{0 , 3 2 1}$ & Valid \\
& $\mathbf{0 , 5 0 3}$ & Valid \\
\hline
\end{tabular}

Sumber:data dolah 2018

Dari tabel 4.4 maka dapat dilihat Corrected Item-total Correlation dari masing-masing variabel lebih besar 0,3 yang berarti kuesioner yang merupakan indikator dari setiap variabel penelitian ini adalah valid.

b. Uji Reliabiltas. Pada penelitian ini uji reliabilitas dilakukan pada setiap instrumen dalam suatu variabel. Instrumen penelitian dikatakan reliabel apabila memiliki nilai Cronbach's Alpha lebih dari 0,6. Nilai Cronbach's Alpha diperoleh melalui analisis data dengan bantuan software SPSS.

Tabel 4.5

Uji Reliabilitas Person Environment ft $\left(\mathrm{X}_{1}\right)$, Oganization Fit ( $\left.\mathbf{X}_{2}\right)$, dan Kinerja Karyawan (Y)

\begin{tabular}{|c|c|c|}
\hline Variabel & Cronbach's Alpha & Keterangan \\
\hline $\mathrm{X}_{1}$ &, 738 & Reliabel \\
\hline $\mathrm{X}_{2}$ &, 608 & Reliabel \\
\hline $\mathrm{Y}$ &, 664 & Reliabel \\
\hline
\end{tabular}

Sumber: data diolah, 2018

Berdasarkan tabel 4.5 diatas menunjukkan keseuruhan variabel independen person environment fit $\left(\mathrm{X}_{1}\right)$, Organizatin Fit $\left(\mathrm{X}_{2}\right)$, dan variabel dependen kinerja karyawan (Y) dalam kuesioner menunjukkan hasil uji reliabilitas dengan Cronbach's Alpha diatas 0,6. Hal ini menjelaskan bahwa pernyataan dalam kuesioner yang diajukan pada penelitian adalah reliabel.

3. Pengujian Analisis Linear Berganda. Hasil analisis data menggunakan software SPSS disajikan dalam tabel berikut ini:

Tabel 4.6

Model Summary

Model Summary

\begin{tabular}{|l|c|r|r|c|}
\hline Model & $\mathrm{R}$ & R Square & $\begin{array}{c}\text { Adjusted R } \\
\text { Square }\end{array}$ & $\begin{array}{c}\text { Std. } \\
\text { Error of } \\
\text { the } \\
\text { Estimate }\end{array}$ \\
\hline 1 &, $727^{\mathrm{a}}$ &, 528 &, 493 & 1,27779 \\
\hline
\end{tabular}

a. Predictors: (Constant), TOTX2, TOTX1

Sumber: data diolah,2018

Koefisien korelasi (R) sebesar 0.727 menunjukkan adanya hubungan antara variabel independen $\left(\mathrm{X}_{1}\right.$ dan $\left.\mathrm{X}_{2}\right)$ dengan variabel dependen (Y). Dari hasil analisis koefisien korelasi berganda tersebut maka dapat diketahui bahwa keeratan hubungan antara person environment fit dan organization fit terhadap kinerja karyawan adalah positif. 
R Square adalah 0,528 artinya $52,8 \%$ dari variasi kinerja karyawan bisa dijelaskan oleh variabel person environment fit dan organization fit. Sedangkan sisanya yaitu 47,2\% (100\%-52,8\%) dijelaskan oleh variabelvariabel lain yang tidak diteliti dalam penelitian ini.

Tabel 4.7

Hasil analisis persamaan Regresi pengaruh Person Environment Fit dan Organization Fit terhadap Knerja Karyawan

Coefficients $^{\mathrm{a}}$

\begin{tabular}{|c|c|c|c|c|c|c|}
\hline \multirow{2}{*}{\multicolumn{2}{|c|}{ Model }} & \multicolumn{2}{|c|}{ Unstandardized Coefficients } & \multirow{2}{*}{$\begin{array}{c}\text { Standardized } \\
\text { Coefficients } \\
\text { Beta }\end{array}$} & \multirow[t]{2}{*}{$\mathrm{T}$} & \multirow[t]{2}{*}{ Sig. } \\
\hline & & B & Std. Error & & & \\
\hline \multirow{3}{*}{1} & (Constant) & 4,077 & 4,830 & &, 844 &, 000 \\
\hline & TOTX $_{1}$ &, 241 &, 122 & 289 & 1,985 &, 047 \\
\hline & $\mathrm{TOTX}_{2}$ & ,643 & ,168 & ,558 & 3,836 & ,001 \\
\hline
\end{tabular}

a. Dependent Variable: TOTY

Sumber :data di olah,2018

Berdasarkan hasil analisis, diperoleh persamaan regresi person environment fit $\left(\mathrm{X}_{1}\right)$ dan organization fit $\left(\mathrm{X}_{2}\right)$ berpengaruh terhadap kinerja karyawan $(\mathrm{Y})$ pada PT. Bank Sulselbar Cabang Palopo sebagai berikut :

$$
\begin{aligned}
& Y=a+b_{1} X_{1}+b_{2} X_{2} \\
& Y=4,077+0,241 X_{1}+0,643 X_{2}
\end{aligned}
$$

Dari hasil analisis menghasilkan nilai koefisien regresi dapat dijelaskan sebagai berikut :

a. Dari persamaan regresi diatas, diperoleh nilai konstanta sebesar 4,077 yang menunjukkan bahwa jika tidak ada kenaikan person environment fit, maka kinerja karyawan mencapai 4,077. Sedangkan koefisien regresi sebesar 0,241 menunjukkan bahwa setiap ada penambahan satu satuan untuk person environmet fit, maka akan ada kenaikan kinerja karyawan sebesar 0,241. Hasil tersebut diperkuat dengan memperhatikan nilai signifikan sebesar 0,047, maka dengan demikian person environment fit berpengaruh signifikan terhadap kinerja karyawan.

b. Nilai konstanta sebesar 4,077 yang menunjukkan bahwa jika tidak ada kenaikan organization fit, maka kinerja karyawan sebesar 4,077. Sedangkan koefisien regresi sebesar 0,643 menunjukkan bahwa setiap ada penambahan satu satuan untuk organization fit, maka akan ada kenaikan kinerja karyawan sebesar 0,643. Hasil tersebut diperkuat dengan memperhatikan nilai sgnifikan sebesar 0,001, maka demikian organization fit berpengaruh signifikan terhadap kinerja karyawan.

\section{Uji T / Parsial}

Uji T / Parsia pada dasarnya menunjukkan seberapa jauh pengaruh variabel independen secara individual terhadap variabel dependen. Untuk menentukan nilai t tabel degree of freedom $\mathrm{df}=(\mathrm{n}-\mathrm{k}-1)$ dimana $\mathrm{n}$ adalah jumlah sampel dan $\mathrm{k}$ adalah jumlah variabel independen. Dimana jumlah sampel $(30-2-1=27)$ yang berarti $t$ tabelnya adalah 1.7032 .

Hipotesis untuk menguji variabel independen yaitu person environment fit $\left(\mathrm{X}_{1}\right)$, organization fit $\left(\mathrm{X}_{2}\right)$ secara individual terhadap variabel dependen (Y) yaitu kinerja karyawan dapat dirumuskan sebagai berikut :

a. Ho : $b_{1} \cdot b_{2}=0$, besarnya $b_{1}$ tidak berbeda dengan nol, maka pengaruh variabel independen terhadap variabel dependen sebesar nol atau tidak ada. Hal ini menunjukkan bahwa variabel independen tidak berpengaruh signifikan terhadap variabel dependen.

b. Ha : $b_{1} \cdot b_{2} \neq 0$, besarnya $b_{1}$ tidak sama dengan nol, maka pengaruh variabel independen terhadap variabel dependen tidak nol. Hal ini menunjukkan bahwa variabel independen berpengaruh signifikan terhadap variabel dependen.

Maka dapat dijelaskan sebagai berikut :

1) Koefisien $t$ hitung variabel person environment fit $\left(\mathrm{X}_{1}\right)$ sebesar 1,985 > t tabel sebesar 1.7032 dengan tingkat taraf signifikan $0,047<0,05$ dengan $(\mathrm{sig}<$ apha $5 \%=0,05)$ sehingga hipotesis nol (Ho) di tolak dan hipotesis alternatif (Ha) diterima. Ha ini menunjukkan bahwa variabel independen yaitu person environment fit $\left(\mathrm{X}_{1}\right)$ secara individual berpengaruh signifikan terhadap variabel dependen kinerja karyawan (Y).

2) Koefisien t hitung variabel organization fit $\left(\mathrm{X}_{2}\right)$ sebesar 3,836>t tabel sebesar 1.7032 dengan tingkat taraf signifikan $0,001<0,05$ dengan $(\mathrm{sig}<$ apha $5 \%=0,05)$ sehingga hipotesis nol (Ho) di tolak dan hipotesis alternatif (Ha) diterima. Ha ini 
menunjukkan bahwa variabel independen yaitu organization fit $\left(\mathrm{X}_{2}\right)$ secara individual

berpengaruh signifikan terhadap variabel dependen kinerja karyawan (Y).

\section{Uji F / Simultan}

Tabel 4.8

Tabel Uji F Pengaruh Person environment fit dan Organization Fit terhadap Kinerja Karyawan ANOVA $^{\mathrm{a}}$

\begin{tabular}{|l|r|r|r|r|r|}
\hline Model & Sum of Squares & Df & Mean Square & F & Sig. \\
\hline Regression & 49,283 & 2 & 24,641 & 15,092 &, $000^{\mathrm{b}}$ \\
Residual & 44,084 & 27 & 1,633 & & \\
Total & 93,367 & 29 & & & \\
\hline
\end{tabular}

a. Dependent Variable: TOTY

b.Predictors: (Constant), TOTX2, TOTX1

Sumber : data diolah 2018

Pengujian Simultan ini dilakukan untuk mengetahui apakah variabel independen person environment fit $\left(\mathrm{X}_{1}\right)$ dan variabel organization fit $\left(\mathrm{X}_{2}\right)$ secara bersama-sama mempunyai pengaruh signifikan terhadap variabel dependen kinerja karyawan (Y). Untuk menentukan nilai Ftabel degree of freedom $\mathrm{df}=(\mathrm{n}-\mathrm{k}-1)$ dimana $\mathrm{n}$ adalah jumlah sampel dan $\mathrm{k}$ adalah jumlah variabel independen. Dimana jumlah sampel $(30-2-1=27)$ yang berarti $F$ tabel adalah 3,35.

Hipotesis untuk menguji variabel independen yaitu person environment fit $\left(\mathrm{X}_{1}\right)$, organization fit $\left(\mathrm{X}_{2}\right)$ secara bersama-sama berpengaruh terhadap variabel dependen (Y) yaitu kinerja karyawan dapat dirumuskan sebagai berikut :

a. Ho : $b_{1} \cdot b_{2}=0$, besarnya $b_{1}, b_{2}$ tidak berbeda dengan nol, maka pengaruh variabel independen terhadap variabel dependen sebesar nol atau tidak ada. Hal ini menunjukkan bahwa variabel independen secara bersama-sama tidak berpengaruh signifikan terhadap variabel dependen.

b. Ha : $b_{1} \cdot b_{2} \neq 0$, besarnya $b_{1}, b_{2}$ tidak sama dengan nol, maka pengaruh variabel independen terhadap variabel dependen tidak nol. Hal ini menunjukkan bahwa variabel independen secara bersama-sama berpengaruh signifikan terhadap variabel dependen.

Tabel 4.8 menunjukkan bahwa nilai $\mathrm{F}$ hitung $>\mathrm{F}$ tabel yaitu 15,092 >3,35dengan nilai signifikan $0,000<$ 0,05 ( $\mathrm{sig}>$ alpha 5\%). Dengan demikian menolak Ho dan menerima Ha yang berarti bahwa variabel $\mathrm{X}_{1}$ dan variabel $\mathrm{X}_{2}$ bersama-sama berpengaruh signifikan terhadap Y.

\section{PEMBAHASAN}

Setelah melakukan pengujian mengenai pengaruh person environment fit (X1) dan organization fit (X2) terhadap kinerja karyawan (Y) dengan regresi linear berganda, uji t statistik, uji F statistik, maka akan dibahas sebagai berikut :

1. Koefisien korelasi (R) sebesar 0,727 menunjukkan adanya hubungan antara variabel independen $\left(\mathrm{X}_{1}\right.$ dan $\mathrm{X}_{2}$ ) dengan variabel dependen $(\mathrm{Y})$. Dari analisis koefisien korelasi berganda tersebut, maka dapat diketahui bahwa keeratan hubungan antara person envirnment fit dan organization terhadap kinerja karyawan adalah positif. Jika R Square / koefisen determinasi adalah 0,528 artinya $52,8 \%$ dari variasi kinerja karyawan bisa di jelaskan oleh variabel person environment fit dan organization fit. Sedangkan sisanya yaitu $47,2 \% \quad(100 \%-52,8 \%)$ dijelaskan oleh variabel-variabel lain yang tidak diteliti dalam penelitian ini.

2. Hasil analisis regresi linear berganda pengaruh person environment fit $\left(\mathrm{X}_{1}\right)$ dan organization fit $\left(\mathrm{X}_{2}\right)$ terhadap kinerja karyawan (Y) pada PT. Bank Sulselbar Cabang Palopodapat dijelaskan sebagai berikut :

a) Koefisien regresi person environment fit $\left(\mathrm{X}_{1}\right)$ sebesar 0,241 menyatakan bahwa jika person environment fit mengalami penambahan satu satuan maka kinerja karyawan meningkat sebesar 0,241 dengan mengganggap $\left(\mathrm{X}_{2}\right)$ dalam keadaan konstan. Hasil ini menunjukkan bahwa semakin tinggi person environment fit yang dikerjakan semakin tinggi pula kinerja karyawan yang dihasikan, sebaliknya semakin rendah person environment fit yang dikerjakan semakin renda pula kinerja karyawan yang dihasilkan.

b) Koefisien regresi organization fit $\left(\mathrm{X}_{2}\right)$ sebesar 0,643 menyatakan bahwa jika organization fit mengalami penambahan satu satuan maka kinerja karyawan meningkat sebesar 0,643 dengan menganggap $\mathrm{X}_{1}$ dalam keadaan konstan. Hasil ini menunjukkan bahwa semakin besar organizatin $f t$ yang diciptakan semakin besar pula kinerja karyawan yang dihasilkan, sebaliknya semakin kecil organization fit yang dibuat semakin kecil pula kinerja karyawan yang dihasilkan.

3. Berdasarkan uji t statistik diperoleh hasil analisis sebagai berikut :

a) t hitung variabel person environment fit $\left(\mathrm{X}_{1}\right)$ sebesar $1,985>\mathrm{t}$ tabel 1.7032dengan tingkat taraf signifikan $0,047<0,05$ dengan ( $\mathrm{sig}<$ alpha $5 \%$ ) sehingga hipotesis nol (Ho) ditolak dan hipotesis alternatif (Ha) diterima. Hal ini menunjukkan bahwa variabel independen yaitu 
person environment fit $\left(\mathrm{X}_{1}\right)$ secara individua berpengaruh signifikan terhadap variabel dependen kinerja karyawan (Y).

b) t hitung variabel organization fit $\left(\mathrm{X}_{2}\right)$ sebesar 3,836> $\mathrm{t}$ tabel 1.7032dengan tingkat taraf signifikan $0,001<0,05$ dengan $($ sig $<$ alpha $5 \%$ ) sehingga hipotesis nol (Ho) ditolak dan hipotesis alternatif (Ha) diterima. Hal ini menunjukkan bahwa variabel independen yaitu organization fit $\left(\mathrm{X}_{2}\right)$ secara individual berpengaruh signifikan terhadap variabel dependen kinerja karyawan (Y).

4. Berdasarkan uji $\mathrm{F}$ menunjukkan bahwa nilai $\mathrm{F}$ hitung > F tabel yaitu 15,092>3,35 nilai ini signifikan dengan $0,000<0,05 \quad(\mathrm{sig}<\quad$ alpha $5 \%=0,05)$. Dengan demikian menolak Ho dan menerima Ha yang berarti bahwa variabel person environment fit $\left(\mathrm{X}_{1}\right)$ dan variabel organization fit $\left(\mathrm{X}_{2}\right)$ secara bersama-sama berpengaruh signifikan terhadap kinerja karyawan (Y) pada PT. Bank Sulselbar Cabang Palopo diterima dan terbukti kebenarannya.

5. Dalam pembahasan ini diarahkan untuk menganalisis sejauh mana pengaruh person environment fit dan organization fit terhadap kinerja karyawan pada PT. Bank Sulselbar Cabang Palopo dan nampak bahwa kedua variabel tersebut berpengaruh signifikan terhadap kinerja karyawan pada PT. Bank Sulselbar Cabang Palopo. Dengan adanya person environment fit yang tinggi maka karyawan akan bersedia menerima hampir semua tugas dan tanggungjawab yang diberikan padanya dan merasakan adanya loyalitas ikut dan rasa memiliki.

Faktor yang mempengaruhi person environment fit $\left(X_{l}\right)$ sehingga berpengaruh signifikan terhadap kinerja karyawanyaitu :

a. Dari hasi analisis menunjukkan bahwa rata-rata responden menyatakan ada pengaruh motivasi karyawan terhadap kinerja karyawan yang ada pada PT. Bank Sulselbar cabang Palopo yaitu:

1) Pertama kali seseorang termotivasi untuk bekerja karena adanyakebutuhan fisik seperti kebutuhan hidup, dimana dalam perusahaan, kebutuhan ini akan terpenuhi manakalah tenaga kerja atau individu mendapatkan upah minimum yang mereka kehendaki, lingkungan pekerjaan yang nyaman, dan lokasi yang bersih dari polusi.

2) Kebutuhan keamanan dimana kebutuhan keamanan ini bukan sekedar untuk merasa aman dari berbagi gangguan fisik maupun mental, akan tetapi juga perasaan aman akan ketidak pastian dimasa yang akan datang seperti rencana pasca pensiunan dari pekerjaan, tunjangan di hari tua, dan lain sebagainya.

3) Setelah kebutuhan fisik dan keamanan terpenuhi, kebutuhan selanjutnya yang akan memotivasi tenaga kerja adalah kebutuhan untuk berinteraksi dan diterima oleh lingkungan sosial. Perusahaan dapat memenuhi kebutuhan ini melalui penciptaan kondisi yang memungkinkan para tenaga kerja untuk berinetraksi satu sama lain dalam pekerjaannya secara lebih fleksibel dan terbuka.

4) Kebutuhan akan penghargaan merupakan salah satu kebutuhan yang akan memotivasi karyawan. Kebutuhan ini berupa penghargaan dari lingkungan sekitar, dari atasan, maupun adanya kejelasan atas penghargaan bagi karyawan yang berprestasi.

5) Kebutuhan aktualisasi diri. Kebutuhan iniberupa adanya tuntutan untuk pengembangan karier yang jelas, pekerjaan yang menantang, dan lain-lain.

b. Dari hasil analisis menunjukkan bahwa rata-rata responden menyatakan ada pengaruh kemampuan karyawan terhadap kinerja karyawan yang ada pada PT. Bank Sulselbar cabang Palopo karena seorang karyawan harus memiliki kemampuan atau skill pada dirinya agar supaya dapat menyelesaikan tugas tepat waktunya serta pekerjaan yang diberikan sesuai dengan kemampuannya.

Karyawan juga ikut memperhatikan nasib organisasi yang akhirnya menimbulkan kinerja karyawan untuk lebih giat bekerja. Dengan demikian organization fit $\left(X_{2}\right)$ yang nyaman dan kondusif maka akan memberikan energi positif bagi karyawan sehingga mereka merasa senang dan selalu bersemangat dan pada akhirnya karyawan akan termotivasi dalam meyelesaikan tugas atau kewajiban mereka masing-masing.

Faktor yang mempengaruhi organization fit $\left(X_{2}\right)$ yaitu:

a. Organization fit $\left(X_{2}\right)$ dari hasil analisis menunjukkan bahwa rata-rata responden menyatakan ada pengaruh leadership terhadap kinerja karyawan yang ada pada PT. Bank Sulselbar cabang Palopo Leadership merupakan faktor yang mendasar yang mempengaruhi organisasi yang ada pada PT.Bank Sulselbar cabang Palopo. Dimana seorang pimpinan mampu mengontrol karyawan jika tidak sesuai dengan pekerjaannya, dan memberikan sanksi tegas jika melanggar aturan, serta memberikan pujian kepada karyawan jika bekerja dengan baik sehingga dapat mempengaruhi kinerja karyawan.

b. Dari hasil analisis menunjukkan bahwa rata-rata responden menyatakan ada pengaruh budaya terhadap kinerja karyawan yang ada pada PT. Bank Sulselbar cabang Palopo. Budaya merupakan faktor mendasar yang ada PT. Bank Sulselbar Cabang Palopo karena dapat menjaga budaya organisasi dierah modern seperti sekarang dan karyawan PT.Bank Sulselbar cabang Palopo dapat memahami budaya 
organisasi sehingga dapat mempengaruhi kinerja karyawan.

c. Dari hasil analisis menunjukkan bahwa rata-rata responden menyatakan iklim organisasi sangat mempengaruhi karakteristik masing-masing karyawan karena sejalan dengan pekerjaan dan perilaku karyawan dapat diterima dilingkungan kerja.

Dari hasil analisis menunjukkan bahwa rata-rata responden menyatakan kinerja karyawan pada PT. Bank Sulselbar Cabang Palopo berpengaruh signifikan terhadap kedua variabel yaitu Person environment fit dan organizaton fit karena mampu menyelesaikan tugas tepat waktu, fasilitas yang disediakan perusahaan dapat mendukung pekerjaan, hubungan atasan dan bawahan berlangsung dengan harmonis, saling bekerjasama dan saling membantu jika mendapatkan kesulitan sehingga dapat mempermudah dalam pencapaian visi misi perusahaan dan menghasilkan prestasi-prestasi yang baik buat perusahaan.

\section{PENUTUP}

\section{Kesimpulan}

Dari hasil penelitian dan pembahasan yang telah dikemukakan maka kesimpulan yang dapat ditarik dalam penelitian ini adalah :

1. Berdasarkan uji $\mathrm{T}$ dapat dijelaskan bahwa person environment fit berpengaruh signifikan terhadap kinerja karyawan. Hal ini ditunjukkan dengan $\mathrm{T}$ hitung $>\mathrm{T}$ tabel $1,985>1.7032$ dengan tingkat signifikan sebesar $0,047<0,05$. Dan organization fit berpengaruh signfikan terhadap kinerja karyawan di tunjukkan dengan 3,836 $>1.7032$ dengan tingkat signifikan $0,001<0,05$ dari taraf signifikan $(\operatorname{sig}<0,05)$.

2. Berdasarkan hasil uji $\mathrm{T}$ diatas, dapat ditarik kesimpulan bahwa person environment fit dan organization fit berpengaruh signifikan terhadap kinerja karyawan. Namun yang paling berpengaruh dari variabel tersebut adalah variabel organization fit karena dalam perusahaan yang dibutuhkan adalah kerjasama yang baik serta memiliki kemampuan yang dapat menciptakan interaksi antara atasan dan karyawan, serta karyawan dengan karyawan yang lainnya.

3. Dari uji $\mathrm{F}$ diperoleh $\mathrm{F}$ hitung $>\mathrm{F}$ tabel yaitu $15,092>3,35$ dan nilai signifikan $0,000<0,05$ yang mana $(\operatorname{sig}<0,05)$. Dengan demikian dapat dikatakan bahwa variabel person environment fit dan organization fit berpengaruh signifikan terhadap kinerja karyawan pada PT. Bank Sulselbar Cabang Palopo.

\section{Saran}

Adapun saran dari penelitian ini adalah sebagai berikut :

1. Pihak PT. Bank Sulselbar cabang Palopo hendaknya mempertahankan person environment fit dan organization fit yang telah terbentuk karena sangat berpengaruh signifikan terhadap kinerja karyawan.

2. Agar dapat memperoleh hasil yang baik, maka peneliti yang akan datang sebaiknya menambahkan variabel independen lain yang mungkin dapat mempengaruhi kinerja karyawan.

\section{DAFTAR PUSTAKA}

Dessler, Gary. 2000. Manajemen Sumber Daya Manusia. Edisi kesepuluh, jilid kesatu. Jakarta : Indeks.

Fathoni, Abdurrahmat. 2006. Manajemen Sumber Daya Manusia. Cetakan pertama. Jakarta : PT. Rineka Cipta.

Ghozali, Imam. 2005. Analisis Multivariate dengan Program SPSS. Edisi kelima. Semarang : Badan Penerbit Universitas Diponegoro.

Mangkunegara Anwar Prabu, 2005, Evaluasi Kinerja Sumber Daya Manusia, cetakan pertama, Penerbit : Aditima Bandung

Rachmawati, Ike Kusdyah. 2008. Manajemen Sumber Daya Manusia, Edisi Pertama, Cetakan satu, Yogyakarta : ANDI

Riduwan. 2003.Dasar-dasar Statistik. Bandung : Alfabeta

Rivai, Veithzal, 2009, Manajemen Sumber Daya Manusia untuk perusahaan, edisi pertama, cetakan kedua, Penerbit : Rajagrafindo Persada, Jakarta.

Robbins. P. S., 2002, Prinsip-prinsip Perlaku Organisasi. Edisi kelima, penerbit : Erlangga, Jakarta.

Rucky S, Achmad, 2006 ,SDM Berkualitas Mengubah Visi Menjadi Realitas, cetakan kedua, Penerbit : Gramedia Pustaka Utama, Jakarta.

Simanjutak, Payaman J, 2005, Manjemen dan Evaluasi Kinerja, edisi pertama, cetakan pertama, Lembaga Penerbit Fakultas Ekonomi Universitas Indonesia, Jakarta.

Sugiyono, 2011.Metode Penelitian Kombinasi (Mixed Methods), Bandung, Alfabeta.

Timpe, A., Dale. 1999. Kinerja (Performance). Jakarta : PT. Gramedia ASM Media

Wibowo, 2008, Manajemen Kinerja, edisi kesatu, penerbit : PT. Raja Grafindo Persada, Jakarta 